\title{
THE ACTION OF CORTISONE AND DESOXYCORTICOSTERONE ACETATE ON GLOMERULAR FILTRATION RATE AND SODIUM AND WATER EXCHANGE IN THE ADRENALECTOMIZED DOG
}

\author{
BY OLIVER GARROD,1 S. A. DAVIES, AND GEORGE CAHILL, Jr.
}

(From the College of Physicians and Surgeons, Columbia University, New York, N. Y.)

(Submitted for publication December 1, 1953; accepted February 2, 1955)

Adrenal failure causes a complex disturbance of renal function and of sodium and water exchange. In the dog, as in man, the ability to conserve sodium is impaired $(1,2)$, there is a fall in glomerular filtration rate and renal blood flow $(3-6)$, and diuresis from water ingestion is much delayed $(7,8)$.

There have been many reports of the effects of corticosteroids on discrete renal functions such as filtration rate or excretion of water and electrolytes in adrenal insufficiency. There have, however, been few attempts to correlate the changes in these renal functions, one with another and with the level of bodily hydration. Thus, from existing data, the effects of changes in filtration rate on other renal functions, or of changes in bodily hydration on filtration rate, cannot be clearly defined in relation to the action of corticosteroids.

The steroids most examined for their renal effects have been desoxycorticosterone acetate (DCA) and, to a much lesser extent, cortisone. Though DCA appears to act mainly on electrolyte excretion, yet, when given in larger amounts than are needed for optimal sodium balance, it may then correct the low filtration rate of adrenalectomized dogs $(4,8,9)$. It is not clear, however, whether this last effect is mainly or wholly dependent on excessive sodium retention, for no comparable studies appear to have been made at deliberately optimal levels of sodium balance $(10,11)$.

Cortisone seems to be more active than DCA in restoring filtration rate (12-14) and water diuresis $(15,16)$, and, by mechanisms which are not yet understood, it can either increase or diminish the sodium output $(14,15,17-19)$. There

\footnotetext{
1 During tenure of a Rockefeller Travelling Fellowship in Medicine, 1951-1952. Present address: Institute of Clinical Research, The Middlesex Hospital, London, W. 1.
}

is little information about its effects in the adrenalectomized dog $(14,20)$.

The investigations reported in this paper are an attempt to define more precisely the renal actions of cortisone and DCA, with special reference to their effects on filtration rate and on sodium and water exchange.

\section{EXPERIMENTAL PLAN AND METHODS}

Renal function was studied in two trained female mongrel dogs, before and after bilateral adrenalectomy, with the following objects: (a) to measure the effects of adrenalectomy on GFR and renal excretion of water and electrolytes, under controlled conditions of bodily hydration, but during escape from direct corticosteroid effects; (b) to compare the acute effects of cortisone and DCA on these renal functions, after adrenalectomy; and (c) to correlate the changes in these different renal functions with one another and with the state of bodily hydration.

\section{Maintenance of the dogs}

The dogs weighed $16^{2}$ and $20 \mathrm{Kgm}$. They lived under optimal conditions on a constant diet to which $2 \mathrm{gm}$. of sodium chloride was added. ${ }^{3}$ They were fed between 1 and 3 P.M. and had free access to water. After a twostage adrenalectomy, a state of optimal bodily hydration was maintained by daily intramuscular injection, at the time of each meal, of 0.6 to $0.75 \mathrm{mg}$. of DCA in sesame oil. In dog $A$ changes in bodily hydration were induced by raising or lowering the DCA dosage (range, 0.5 to $1.5 \mathrm{mg}$. a day). Therapy was controlled by daily weighing and frequent measurements of fasting plasma specific gravity, electrolyte concentrations, blood urea, and hematocrit. Plasma volumes were measured by the T-1824 dye method (21), using a Beckmann spectrophotometer.

The diurnal patterns of water, creatinine, and electrolyte excretion were determined, in relation to meals and DCA injections.

2 Dog A was not fully grown at the beginning of these studies (initial weight, $15.5 \mathrm{Kgm}$.; final weight, $18 \mathrm{Kgm}$.).

8 The total daily intake was approximately $90 \mathrm{mEq}$. sodium and $62 \mathrm{mEq}$. potassium. 


\section{Measurements of renal function}

Usual procedure. After free access to water overnight, 15-minute urine collections were started between 8 and 9 A.M. Half an hour later, a priming infusion of creatinine and $\mathrm{PAH}^{4}$ was slowly injected, followed by a sustaining infusion which was continued throughout the experiment. A 45-minute period was allowed for equilibration. After three or more clearance periods, $40 \mathrm{ml}$. of warm water per $\mathrm{Kgm}$. were given by stomach tube. Clearances were then measured for a further three to six hours.

The following renal functions were determined: GFR, ERPF, urinary $\mathrm{pH}$, and urinary outputs of sodium, potassium, chloride, and phosphate.

Blood was taken initially and at the midpoint of every third or fourth clearance period, and the red cells reinfused at the end of each experiment. Plasma creatinine, $\mathrm{PAH}$, specific gravity, and electrolyte concentrations were measured in each sample.

The above-mentioned procedure was carried out under the following conditions: (i) before adrenalectomy, (ii) after adrenalectomy, while on optimal DCA therapy, and, in $\operatorname{dog} \mathrm{A}$, also when on inadequate and excessive DCA therapy and after intravenous saline infusion, and in both dogs during acute administration of cortisone and DCA.

To observe its effects, both with and without a water load, cortisone was given, in separate experiments, three hours before the water dose, or at the time of the water dose, or three hours after it. The cortisone was given in one of three different ways: (i) intravenously, as a microcrystalline suspension of $50 \mathrm{mg}$. cortisone acetate in $1 \mathrm{ml}$. distilled water, dose 10 to $50 \mathrm{mg}^{\mathrm{b}}$; (ii) intravenously, as cortisone tricarballylate, ${ }^{6}$ dose 30 to $90 \mathrm{mg}$. freshly dissolved in a few $\mathrm{ml}$. of isotonic saline, or (iii) orally, as cortisone acetate (Cortone 1 , Merck), dose 50 mg.

DCA was injected intravenously as a microcrystalline suspension in distilled water, made to the same specifications as the cortisone acetate, ${ }^{5}$ dose 2.5 to $5.0 \mathrm{mg}$. It was given three hours after the water dose.

Other procedures. On 47 occasions the diuretic response to the standard water dose (supra) and the accompanying outputs of sodium and potassium were measured for three hours without determining GFR and ERPF.

4 The priming infusion consisted of hypertonic creatinine and PAH in about $60 \mathrm{ml}$. of distilled water. The sustaining infusion consisted of approximately isotonic creatinine and PAH, and was given at a steady rate of 24 to $30 \mathrm{ml}$. per hour. The effects of these infusions on water and electrolyte excretion were measured during equilibration, and on GFR and ERPF during succeeding periods totalling 45 to 60 minutes, before the water dose was given.

- Specially prepared by Chemical Specialities, Inc., N. Y.

- A water-soluble but unstable ester, specially prepared by Merck, Ltd., N. J.
In another group of experiments the effects of intravenous cortisone acetate, and of DCA, on excretion of water, electrolytes, and endogenous creatinine were measured but, without the complicating effects of an infusion or water dose.

\section{Chemical methods}

The methods used for the following chemical estimations are indicated by the references: sodium and potassium, by an internal lithium standard flame photometer (22) having an error of less than one per cent; plasma and urinary chloride (23) ; plasma and urinary creatinine (24) ; PAH (25) ; urinary phosphate (26) ; blood urea nitrogen (27); plasma specific gravity $(28,29)$. The urinary $\mathrm{pH}$ was measured by indicators within one-half minute of urine collection.

\section{RESULTS}

\section{Water and Electrolyte Balance in Relation to Chronic DCA Therapy After Adrenalectomy}

\section{Assessment of bodily hydration}

Adequacy of the DCA therapy was assessed by observing the weight, appetite, and activity

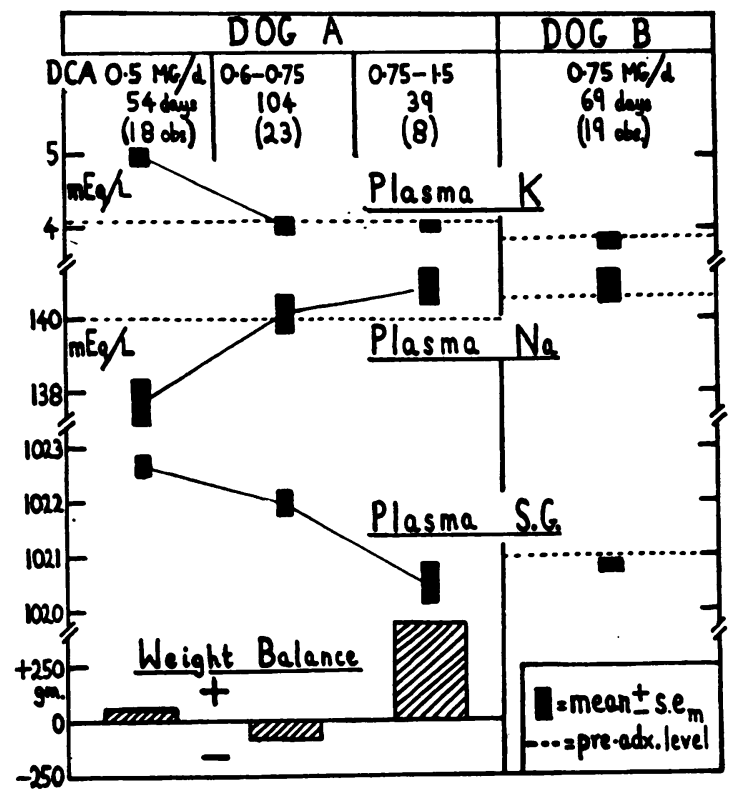

Fig. 1. The Effects of DCA Therapy on Fasting Plasma Concentrations in the Two AdrenalectoMIZED Dogs

In $\operatorname{dog} \mathrm{A}$, optimal therapy was achieved on 0.6 to $0.75 \mathrm{mg}$. DCA a day, in $\operatorname{dog} B$ on $0.75 \mathrm{mg}$. a day. The weight balances in $\operatorname{dog} A$ are the means of daily deviations from the growth-weight curve during the total period of the studies. The slight rise in weight during inadequate DCA therapy was due to water retention, and the rise during excessive DCA therapy to salt and water retention. 


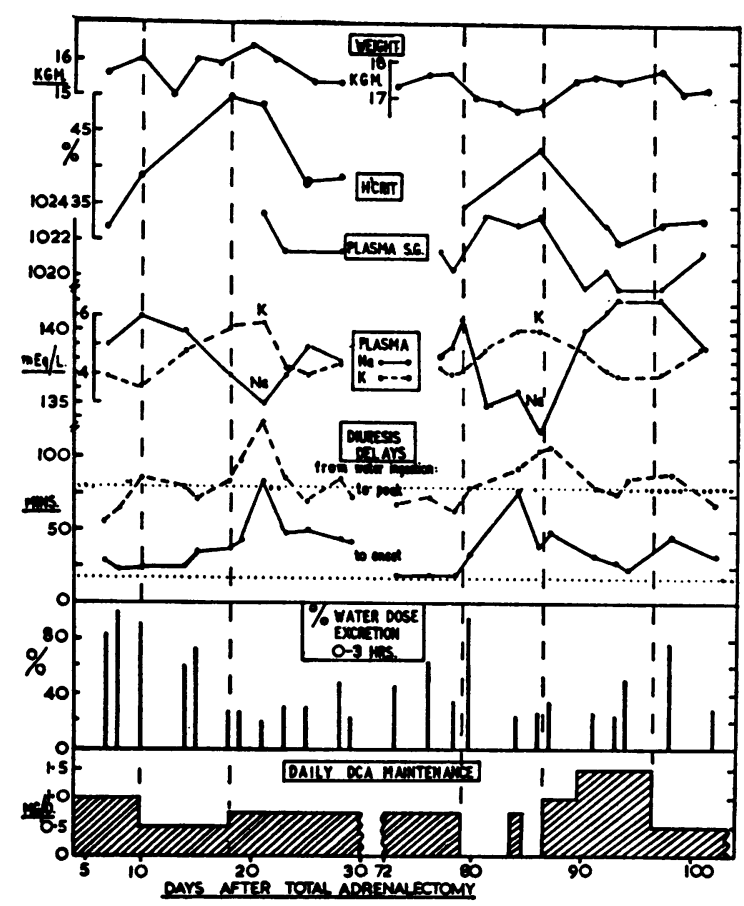

Fig. 2. Water Diuresis and Plasma Concentrations Relative to DCA Therapy in AdrenalectoMIzed Dog A

Two sample periods are shown. Diet and sodium intake were constant. The body weight and plasma concentrations were obtained after 18 hours' fasting with free access to water, before giving the standard water dose of $40 \mathrm{ml}$. per $\mathrm{Kgm}$. body weight. Dotted lines indicate the delay in diuresis before adrenalectomy. The body weights have not been corrected for growth.

of the dogs, and by comparing their fasting plasma specific gravities and electrolyte concentrations with the levels obtained before adrenalectomy (Figure 1). In $\operatorname{dog} \mathrm{A}$, a state of optimal health and bodily hydration was achieved on 0.6 to 0.75 mg. DCA per day, in dog B on $0.75 \mathrm{mg}$. per day. At this dosage their plasma volumes varied between 5 and 5.7 per cent of body weight, figures comparable with the mean of 5.4 per cent reported by Courtice in 29 intact mongrel dogs (30). In dog A the dose of DCA was deliberately varied so that the effects of changes in bodily hydration could be studied. Inadequate DCA therapy (e.g., 0.5 to $0.6 \mathrm{mg}$.) was followed by a rise in hematocrit, plasma specific gravity and potassium and a fall in plasma sodium; the expected loss of weight did not always occur (Figure 1) because of water retention, apparently intracellular, from the repeated water doses (Figure 2).
Excessive DCA therapy (e.g., 1 to $1.5 \mathrm{mg}$.) caused excessive gain in weight, a fall in plasma specific gravity, and a slight rise in plasma sodium concentration (Figures 1 and 2). The plasma specific gravity was the most sensitive index of hydration; the hematocrit and plasma sodium and potassium were almost as sensitive to inadequate, but not to excessive, therapy; blood urea was an unreliable index.

In order that renal function could be assessed in relation to bodily hydration, the renal data were grouped as follows: 1) optimal therapy, all periods on 0.6 to $0.75 \mathrm{mg}$. DCA per day, ${ }^{7}$ ) inadequate therapy all periods on less than $0.6 \mathrm{mg}$. per day, 3) excessive therapy, all periods on 1 to $1.5 \mathrm{mg}$. per day, and in $\operatorname{dog} \mathrm{A}$, on $0.75 \mathrm{mg}$. for more than six weeks. ${ }^{\text {? }}$

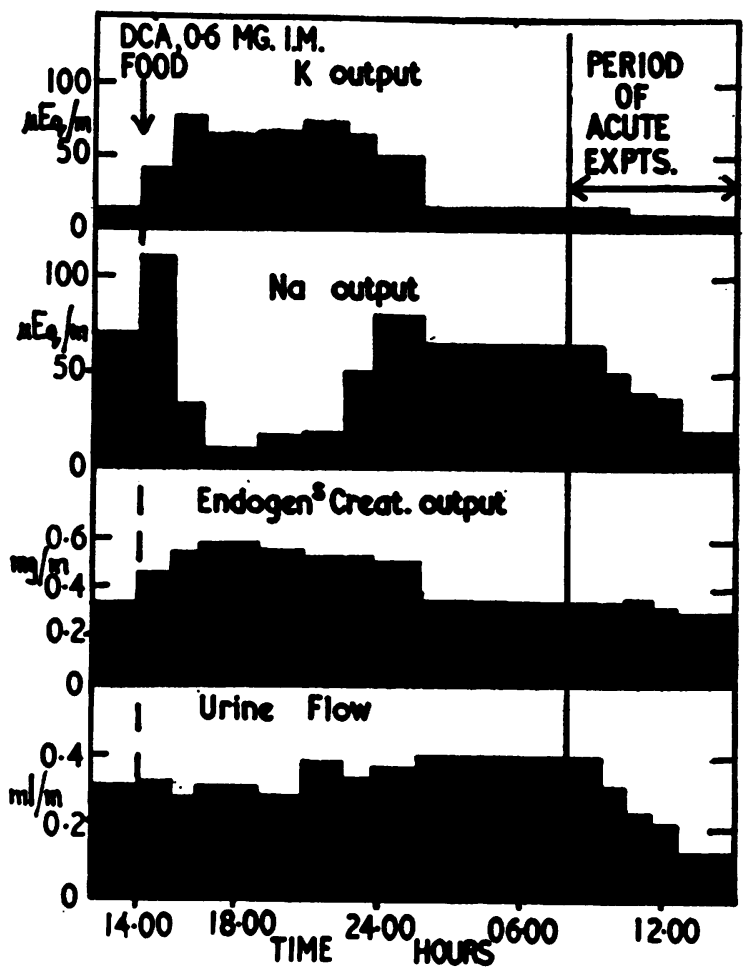

Fig. 3. Diurnal Variations in Urinary Excretion Rates Dependent on FeEding and DCA Therapy, in Adrenalectomized Dog A

Free access to water was allowed throughout the 24 hour period. The pattern of urinary excretion was similar on other occasions, and in both dogs. Note the transient effect of the DCA injection.

${ }^{7}$ In dog A clear signs of overdosage appeared after six weeks on $0.75 \mathrm{mg}$. DCA per day. The optimal dosage was probably nearer 0.6 than $0.75 \mathrm{mg}$. per day. 


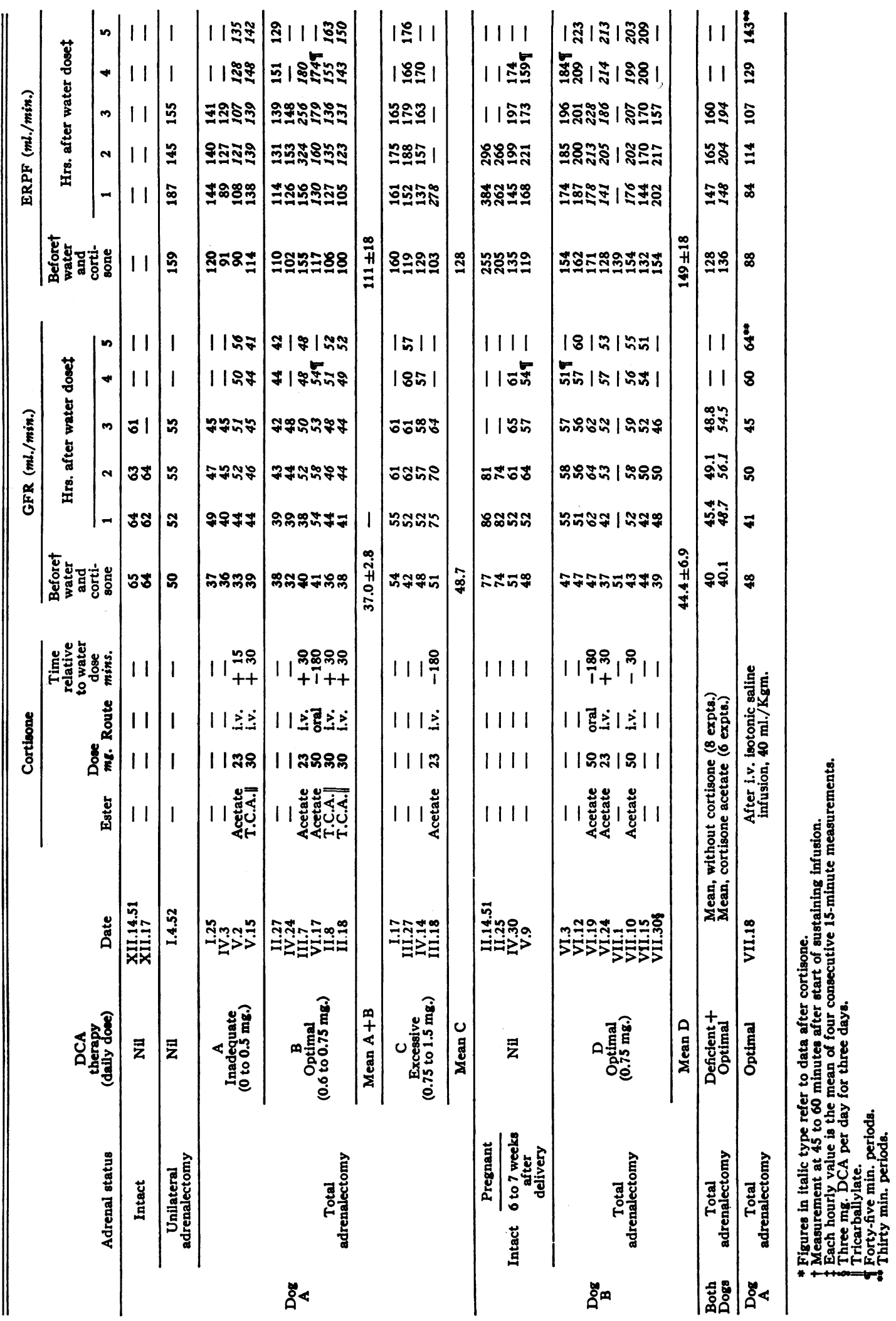




\section{Duration of action of the therapeutic DCA in- jections}

The sodium-retaining action of the DCA injections ceased after about eight hours in dog A (Figure 3) and after 12 to 18 hours in dog B. There was then a delayed excretion of the dietary sodium. From 18 to 24 hours after the DCA, which is the period when renal function was studied, the sodium excretion remained steady or fell further; the kidneys had then escaped from DCA effect.

\section{Renal Function}

Glomerular filtration rate (GFR) and renal plasma flow $(E R P F)^{8}$

(a) Effects of adrenalectomy, relative to $D C A$ therapy (Table I). In $\operatorname{dog} \mathrm{A}$, after adrenalectomy, GFR was consistently subnormal when on optimal DCA therapy, but rose after water ingestion. On excessive DCA therapy GFR was higher and sometimes became normal after water ingestion. Changes in ERPF were essentially parallel.

In dog B, GFR fell to subnormal levels during the second month after adrenalectomy, but throughout the post-operative period it rose less after water than before adrenalectomy. A short period of excessive DCA therapy in this dog (3 mg. a day for three days) did not raise the GFR (Table I), but there was no accompanying retention of sodium and water.

(b) Acute effects of $D C A$ on GFR. Intravenous DCA (2.5 to $5 \mathrm{mg}$.), though it caused almost maximal reabsorption of sodium by the tubules, did not increase GFR, ERPF, or endogenous

\footnotetext{
8 The effects on GFR and ERPF of the infusions used in measuring them need to be considered. During nine experiments in $\operatorname{dog} \mathrm{A}$, there was a consistent rise in GFR of $11 \pm$ s.d. $3.7 \mathrm{ml}$. per minute, and in ERPF of $8 \pm$ s.d. $2 \mathrm{ml}$. per min. between 45 and 90 minutes after starting the sustaining infusion. Though a similar rise did not occur in $\operatorname{dog} \mathrm{B}$, a rise in this dog's sodium excretion within 30 mins. of starting the sustaining infusion suggested that GFR had already risen during the period of equilibration when it could not be measured directly. Thus, in both dogs the true fasting GFR was probably less than that of the first period of creatinine clearance at the end of equilibration. To ensure standardization, the fasting GFR and ERPF have been taken from the first 15-minute clearances after equilibration, i.e., 45 to 60 minutes after starting the sustaining infusion.
}

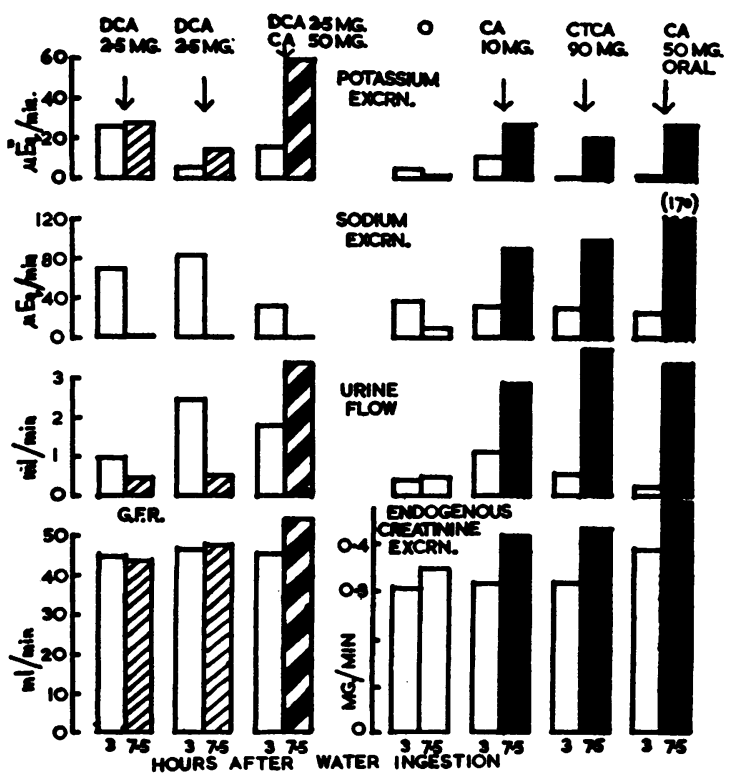

Fig. 4. The Acute Effects of DCA and Cortisone on Urinary Excretion Rates when Given Three Hours after Water Ingestion, in Adrenalectomized Dog A

Ingestion of the standard water dose was followed by a subnormal diuresis which was subsiding at three hours when the steroid was given. Cortisone caused a rise in GFR or endogenous creatinine excretion and return of water diuresis. DCA had no effect on GFR or water diuresis. Each excretion rate shown covers a 45minute period ending at three, or seven and one-half hours after water ingestion, as indicated at the bottom of the graph. After DCA, sodium excretion was less than $4 \mu \mathrm{Eq}$. per minute. $\mathrm{CA}=$ cortisone acetate, $\mathrm{CTCA}=$ cortisone tricarballylate, given I.V. except when specified.

creatinine excretion, or augment the effect of cortisone on these functions (Figure 4, Table II).

(c) Acute effects of cortisone on GFR.

(i) Without water ingestion. In both dogs 50 mg. of intravenous cortisone acetate caused a mean 30 per cent rise in endogenous creatinine output which began within one to two hours (Table II). That this was due to the acute rise in GFR was confirmed in $\operatorname{dog} \mathrm{A}$; within three and one-half hours of intravenous injection of $23 \mathrm{mg}$. of cortisone acetate GFR had risen from 53 to 68 $\mathrm{ml}$. per minute, and ERPF from 116 to $222 \mathrm{ml}$. per minute (Table III).

(ii) Accompanying, or preceding, water ingestion. The rise in GFR and ERPF from water ingestion was greater with cortisone than 
TABLE II

The acute effects of cortisone acetate and DCA on fasting urinary excretion rates in two adrenalectomised dogs (on steady optimal DCA therapy) *

\begin{tabular}{|c|c|c|c|c|c|c|c|c|c|c|c|c|c|c|c|}
\hline \multirow{4}{*}{$\begin{array}{l}\text { Intra- } \\
\text { veenous } \\
\text { steroid } \\
\text { (micro- } \\
\text { crystalg) } \\
\text { at } 0 \text { mins. }\end{array}$} & \multirow{4}{*}{$\begin{array}{l}\text { Time } \\
\text { mins. }\end{array}$} & \multicolumn{7}{|c|}{ Dog A: 5 to 6 months after total adrenalectomy } & \multicolumn{7}{|c|}{ Dog B: 8 to 11 weeks after total adrenalectomy } \\
\hline & & \multicolumn{7}{|c|}{ Excretion rates } & \multicolumn{7}{|c|}{ Excretion rates } \\
\hline & & \multirow{2}{*}{$\begin{array}{l}\text { Urine } \\
\text { mi./ } \\
\text { min. }\end{array}$} & \multirow{2}{*}{$\begin{array}{l}\text { Endog- } \\
\text { enous } \\
\text { creati- } \\
\text { nine } \\
\text { \% of } 1 \text { st } \\
\text { period }\end{array}$} & $\mathrm{Na}$ & $\mathbf{K}$ & $\mathbf{C l}$ & POAt & \multirow{2}{*}{$\begin{array}{l}\text { Urine } \\
\text { pHf }\end{array}$} & \multirow{2}{*}{$\begin{array}{l}\text { Urine } \\
\text { ml./ } \\
\text { mix. }\end{array}$} & \multirow{2}{*}{$\begin{array}{l}\text { Endog- } \\
\text { enous } \\
\text { creati- } \\
\text { nine } \\
\text { \% of 1st } \\
\text { period }\end{array}$} & $\mathbf{N a}$ & $\mathbf{K}$ & $\mathbf{C l}$ & POA & \multirow{2}{*}{$\begin{array}{c}\text { Urine } \\
\text { pH }\end{array}$} \\
\hline & & & & \multicolumn{3}{|c|}{$\mu E q . / \min }$. & & & & & \multicolumn{4}{|c|}{$\mu E_{q .} / \min }$. & \\
\hline $\mathbf{0}$ & $\begin{array}{r}0 \\
60 \\
120 \\
180 \\
240 \\
300\end{array}$ & $\begin{array}{l}0.41 \\
0.39 \\
0.32 \\
0.28 \\
0.27 \\
0.24\end{array}$ & $\begin{array}{r}100 \\
98 \\
93 \\
88 \\
90 \\
91\end{array}$ & $\begin{array}{l}94 \\
89 \\
62 \\
56 \\
42 \\
35\end{array}$ & $\begin{array}{c}16 \\
13 \\
7.6 \\
6.5 \\
5.9 \\
4.4\end{array}$ & $\begin{array}{l}77 \\
78 \\
59 \\
51 \\
39 \\
34\end{array}$ & $\begin{array}{c}27 \\
22 \\
12 \\
10 \\
7.5 \\
6.1\end{array}$ & $\begin{array}{l}7.5 \\
7.5 \\
7.45 \\
7.5 \\
7.55 \\
7.6\end{array}$ & $\begin{array}{l}0.25 \\
0.29 \\
0.27 \\
0.30 \\
0.26 \\
0.28\end{array}$ & $\begin{array}{r}100 \\
97 \\
100 \\
101 \\
103 \\
99\end{array}$ & $\begin{array}{l}37 \\
55 \\
49 \\
58 \\
46 \\
48\end{array}$ & \begin{tabular}{|l|}
21 \\
14 \\
10.6 \\
9.1 \\
8.2 \\
7.3
\end{tabular} & $\begin{array}{l}27 \\
30 \\
31 \\
31 \\
32 \\
34\end{array}$ & $\begin{array}{l}13 \\
12 \\
9.5 \\
8.1 \\
6.1 \\
5.2\end{array}$ & $\begin{array}{l}7.5 \\
7.8 \\
7.8 \\
7.8 \\
7.8 \\
7.7\end{array}$ \\
\hline \multirow[t]{2}{*}{$\begin{array}{c}\text { DCA } \\
2.5 \mathrm{mg} .\end{array}$} & $\begin{array}{r}0 \\
60 \\
120 \\
180 \\
240 \\
300\end{array}$ & $\begin{array}{l}0.45 \\
0.38 \\
0.28 \\
0.19 \\
0.19 \\
0.21\end{array}$ & $\begin{array}{r}100 \\
91 \\
90 \\
92 \\
99 \\
104\end{array}$ & $\begin{array}{l}87 \\
73 \\
20 \\
4.7 \\
3.1 \\
2.8\end{array}$ & $\begin{array}{l}30 \\
22 \\
37 \\
23 \\
23 \\
26\end{array}$ & $\begin{array}{l}87 \\
72 \\
49 \\
27 \\
26 \\
24\end{array}$ & $\begin{array}{l}27 \\
25 \\
17 \\
12 \\
13 \\
16.5\end{array}$ & $\begin{array}{l}7.4 \\
7.1 \\
6.7 \\
6.8 \\
7.1 \\
7.3\end{array}$ & $\begin{array}{l}0.36 \\
0.35 \\
0.23 \\
0.26 \\
0.25 \\
0.25\end{array}$ & $\begin{array}{r}100 \\
99 \\
91 \\
102 \\
108 \\
104\end{array}$ & $\begin{array}{l}91 \\
79 \\
32 \\
31 \\
33 \\
29\end{array}$ & $\begin{array}{l}12 \\
8 \\
21 \\
27 \\
27 \\
16.2\end{array}$ & $\begin{array}{l}70 \\
92 \\
54 \\
57 \\
61 \\
45\end{array}$ & $\begin{array}{l}7.4 \\
4.6 \\
2.9 \\
4.3 \\
9.1 \\
7.1\end{array}$ & $\begin{array}{l}8.0 \\
8.2 \\
7.4 \\
7.3 \\
7.4 \\
7.3\end{array}$ \\
\hline & & \multicolumn{6}{|c|}{ (mean of 3 experiments) } & & \multicolumn{6}{|c|}{ (mean of 2 experiments) } & \\
\hline $\begin{array}{c}\text { Cortisone } \\
\text { acetate } \\
50 \mathrm{mg} .\end{array}$ & $\begin{array}{r}0 \\
60 \\
120 \\
180 \\
240 \\
300\end{array}$ & $\begin{array}{l}0.40 \\
0.37 \\
0.29 \\
0.72 \\
0.86 \\
0.91\end{array}$ & $\begin{array}{l}100 \\
.98 \\
103 \\
115 \\
128 \\
128\end{array}$ & $\begin{array}{r}73 \\
90 \\
33 \\
24 \\
89 \\
146\end{array}$ & $\begin{array}{l}16.2 \\
33 \\
39 \\
47 \\
56 \\
47\end{array}$ & $\begin{array}{r}60 \\
101 \\
50 \\
48 \\
61 \\
53\end{array}$ & $\begin{array}{l}31 \\
23 \\
12 \\
19 \\
34 \\
36\end{array}$ & $\begin{array}{l}7.2 \\
7.6 \\
7.25 \\
7.3 \\
8.0 \\
8.25\end{array}$ & $\begin{array}{l}0.35 \\
0.36 \\
0.77 \\
0.54 \\
0.76 \\
0.83\end{array}$ & $\begin{array}{l}100 \\
107 \\
120 \\
124 \\
129 \\
132\end{array}$ & $\begin{array}{r}85 \\
83 \\
154 \\
109 \\
119 \\
145\end{array}$ & $\begin{array}{c}9.1 \\
22 \\
52 \\
46 \\
35 \\
17\end{array}$ & $\begin{array}{r}78 \\
73 \\
176 \\
133 \\
118 \\
78\end{array}$ & $\begin{array}{c}14 \\
11 \\
11 \\
9.7 \\
16 \\
27\end{array}$ & $\begin{array}{l}7.5 \\
8.1 \\
7.9 \\
7.5 \\
7.8 \\
8.2\end{array}$ \\
\hline
\end{tabular}

* Each hourly output is the mean of two consecutive one-half-hourly outputs. Plasma changes are shown in Table IV t Corrected for urine pH.

$\$$ Measured by indicators within $\mathbf{3 0}$ seconds of urine collection.

TABLE III

The effect of intravenous cortisone on renal function and water balance in adrenalectomized $\operatorname{dog} A$ *

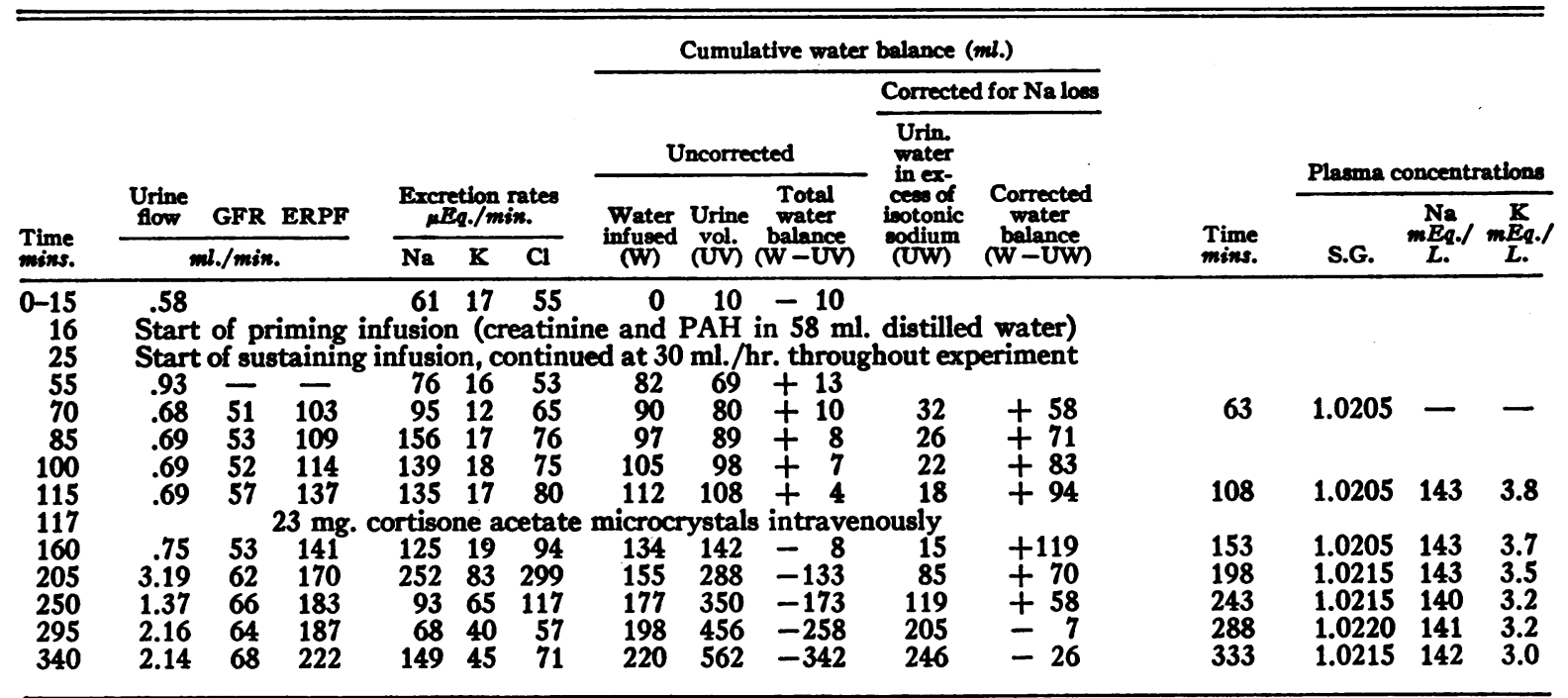

* The dog was on excessive DCA maintenance ( $0.75 \mathrm{mg}$. per day for seven weeks).

Each output shown after cortisone injection is the mean of three consecutive 15-minute observations. 
without (Table I). This increment occurred at about one and one-half hours after $23 \mathrm{mg}$. of cortisone acetate, and at three to three and onehalf hours after an equimolar dose (i.e., $30 \mathrm{mg}$.) of cortisone tricarballylate, irrespective of the level of DCA therapy (Table I).

(iii) Three hours after water ingestion (Figure 4). When cortisone was given three hours after the water dose, orally as the acetate, or intravenously as the acetate or tricarballylate, endogenous creatinine excretion rose by 25 to 33 per cent. Without cortisone it did not rise.

(d) GFR relative to plasma volume and specific gravity. Plasma specific gravity was used as an index of hemodilution and was measured concurrently with GFR during all experiments. Grouped data from the periods without cortisone showed a high inverse correlation between GFR and plasma specific gravity $(r=-0.84)$. Grouped data from the periods between one and six hours after cortisone showed no such correlation ( $r=-.034)$, but GFR was higher relative to plasma specific gravity (Figure 5 ).

Again, in four experiments unaccompanied by infusion or water ingestion, $50 \mathrm{mg}$. of intravenous cortisone acetate had no effect during four hours on plasma volume, specific gravity or electrolyte concentrations; concurrently, however, the en-

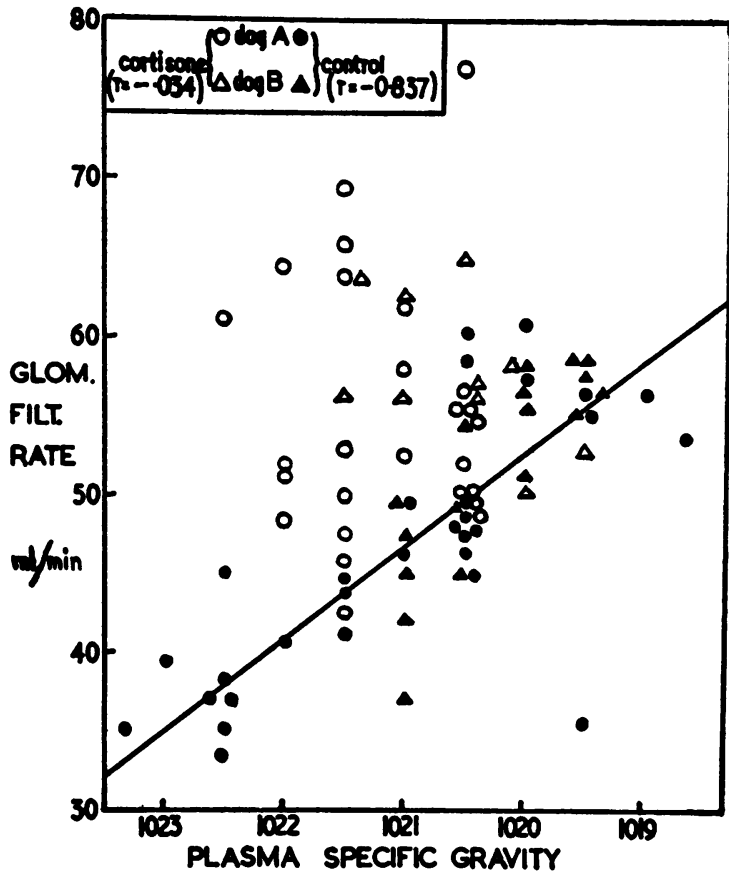

Fig. 5. GFR in Relation to Plasma Specific Gravity, with aNd without Cortisone, in Two Adrenalectomized Dogs

Each GFR plotted is the mean of three consecutive 15minute measurements. Plasma specific gravity (28) was measured at the midpoint of each 45-minute GFR period. All data have been included except those from the first two months after adrenalectomy in $\operatorname{dog} \mathbf{A}$.

TABLE IV

Changes in plasma in relation to changes in endogenous creatinine excretion after cortisone and $D C A$ *

\begin{tabular}{|c|c|c|c|c|c|c|}
\hline \multirow[b]{3}{*}{ Subject } & \multirow{3}{*}{$\begin{array}{c}\text { Steroid at } \\
0 \text { mins. } \\
\text { (Intravenous) }\end{array}$} & \multicolumn{5}{|c|}{ Per cent change at three and three-fourths hours after steroid } \\
\hline & & \multirow{2}{*}{$\begin{array}{c}\text { Endogenous } \\
\text { creatinine } \\
\text { outputf }\end{array}$} & \multicolumn{4}{|c|}{ Plasma } \\
\hline & & & Vol. & S.G.8 & $\begin{array}{l}\mathrm{Na} \\
\text { conc. }\end{array}$ & $\begin{array}{c}\mathrm{Cl} \\
\text { conc. }\end{array}$ \\
\hline & Cortisone & +33 & -4.5 & -1.3 & +0.4 & +1.6 \\
\hline $\operatorname{Dog} A$ & $50 \mathrm{mg}$. & $\begin{array}{l}+36 \\
+21\end{array}$ & -1.4 & $\begin{array}{l}+1.6 \\
+1.7\end{array}$ & $\begin{array}{l}-0.6 \\
-1.4\end{array}$ & $\underline{-0.5}$ \\
\hline Dog B & $\begin{array}{l}50 \mathrm{mg} . \\
50 \mathrm{mg} .\end{array}$ & $\begin{array}{l}+27 \\
+36\end{array}$ & $\begin{array}{l}+12.7 \\
-2.9\end{array}$ & $\begin{array}{l}+0.4 \\
+1.0\end{array}$ & $\begin{array}{l}-0.2 \\
-0.5\end{array}$ & $\begin{array}{l}+0.4 \\
-0.2\end{array}$ \\
\hline \multicolumn{2}{|c|}{ Mean of 5 experiments (both dogs) } & +30.6 & +1.0 & +0.7 & -0.46 & +0.32 \\
\hline $\begin{array}{l}\operatorname{Dog} A \\
\operatorname{Dog} B \\
\operatorname{Dog} A \\
\operatorname{Dog} B\end{array}$ & $\begin{array}{cc}\text { DCA } 2.5 \mathrm{mg} . \\
\text { DCA } 2.5 \mathrm{mg} . \\
0 \\
0\end{array}$ & $\begin{array}{l}-2 \\
+1 \\
-10 \\
+3\end{array}$ & E & $\begin{array}{l}-0.5 \\
+0.9 \\
-1.3 \\
-\end{array}$ & $\begin{array}{l}+0.7 \\
+1.0 \\
-1.0 \\
-\end{array}$ & $\begin{array}{c}+2.1 \\
0 \\
0 \\
-\end{array}$ \\
\hline
\end{tabular}

* These experiments were made during a five-week period of steady optimal DCA therapy, after 18 hours' fasting with free access to water.

$\dagger$ Calculated from the output three and one-half to four hours after, the steroid injection divided by the output during the 60 minutes immediately preceding, the steroid injection.

These measurements were made 15 to 30 minutes before, and repeated three and three-fourths hours after, the steroid injection.

$\$$ Measured by the gradient method of Lowry and Hunter (29). 


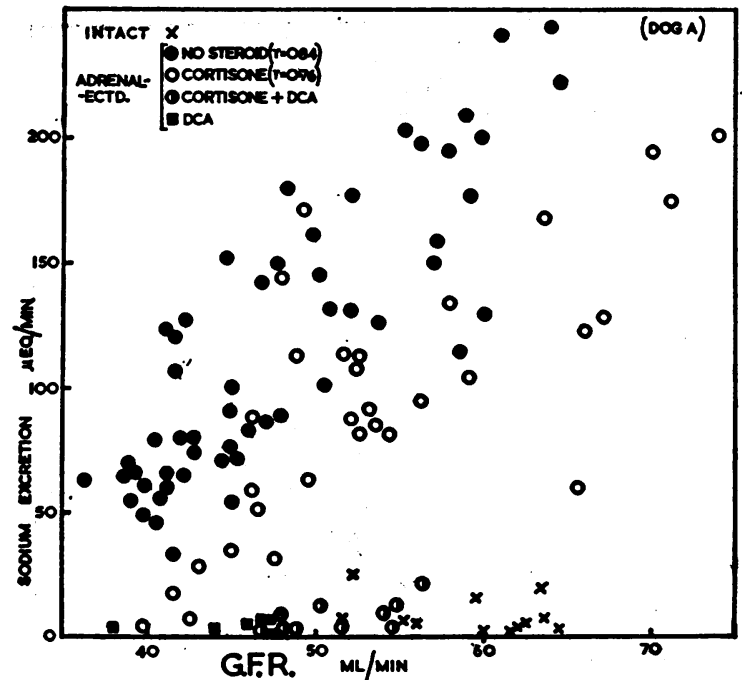

A

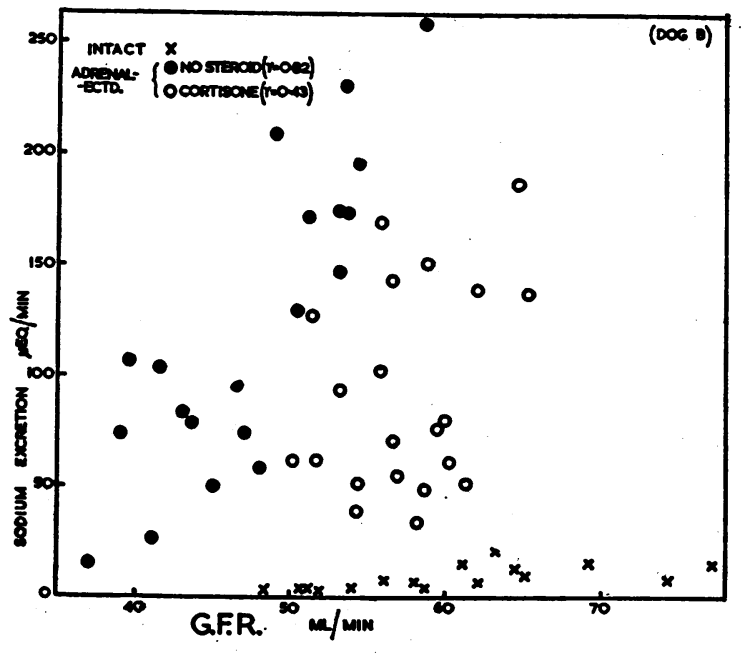

B

Fig. 6A and B. Sodium Excretion in Relation to GFR: the Effects of Cortisone and DCA

Each plotted GFR and sodium excretion rate is the mean of three consecutive 15-minute measurements, without overlap. In dog $\mathrm{A}$ all data have been included. In $\operatorname{dog} \mathrm{B}$, data from the first month after adrenalectomy have been excluded on account of dietary irregularities and unsteady sodium intake.

dogenous creatinine output rose by 30 per cent (Table IV). These findings suggested that the acute effects of cortisone on GFR were not dependent on an increase in plasma volume.

(e) The effect of saline infusion on GFR (Table I). This experiment was designed to find out whether the chronic effects of excessive DCA therapy on GFR could be reproduced acutely, when on optimal DCA therapy, by infusing isotonic saline. Isotonic saline, $40 \mathrm{ml}$. per $\mathrm{Kgm}$. of body weight, was infused during 75 minutes. When the water dose was given at the end of this infusion, GFR was $10 \mathrm{ml}$. higher than the mean fasting level on optimal DCA therapy ( $37.1 \pm$ s.d. $2.8 \mathrm{ml}$. per min.). Four hours later GFR had risen to its pre-adrenalectomized level (Table I). This effect was preceded by defecation, slight edema, and restlessness, suggesting mild water intoxication. Thus, the chronic effects of excessive DCA therapy on GFR were reproduced acutely by overloading with sodium and water; water diuresis, however, was largely inhibited. ${ }^{\circ}$

- Defecation during diuresis experiments in the intact dog is usually accompanied by prolonged antidiuresis (31). This was also our experience on other occasions, in the adrenalectomized dog.

\section{Sodium excretion ${ }^{10}$}

(a) In relation to water diuresis. Before adrenalectomy, even when GFR rose after water ingestion, the fasting sodium output remained low or fell further (Figure 6). After adrenalectomy, water ingestion always raised GFR (Table I), and there was then a parallel rise in the fasting sodium excretion, an effect which was further accentuated when on excessive DCA therapy ${ }^{10}$ (Figure 6).

(b) In relation to $G F R$, without cortisone. On analysis of grouped data from the periods after adrenalectomy, there was a high correlation between GFR and sodium output $(r=0.84$ and 0.82 in the two dogs) (Figure 6).11

10 Before adrenalectomy the sodium output, 18 hours after food, was always less than $25 \mu \mathrm{Eq}$. per minute. After adrenalectomy it was always higher (40 to 100 $\mu$ Eq. per minute), due partly to delayed excretion of dietary sodium which had been retained during the period of action of the injected DCA. This "escape effect" was much greater during excessive DCA therapy, owing to the longer action of the larger DCA injections and the compensating effect of higher GFR (infra).

11 Because the changes in plasma sodium concentration were small, when this data was calculated as the quantity of sodium filtered $\left(\mathrm{Na}^{\mathrm{P}}=\mathrm{Na}^{\mathrm{P}} \times \mathrm{GFR}\right)$ and the percentage reabsorbed by the tubules $(\mathrm{Na} \mathrm{R} / \mathrm{F})$, the correlations were essentially similar. 
(c) In relation to $G F R$, after cortisone. By raising GFR cortisone increased the sodium output. There was still a correlation between GFR and sodium excretion $(r=0.77$ and 0.43 in the two dogs), but for any given level of GFR the rate of sodium excretion was less than when no steroid had been given (Figure 6). ${ }^{11}$ Figure 7 shows typical changes in sodium filtration $\left(\mathrm{Na}^{\mathrm{r}}\right)$ and reabsorption $(\mathrm{Na} \mathrm{R} / \mathrm{F})$ after cortisone. It will be seen that there was an early and persistent rise in $\left(\mathrm{Na}^{\mathrm{r}}\right)$. The fall in sodium reabsorption ( $\mathrm{Na} \mathrm{R} / \mathrm{F}$ ) was, however, interrupted at two to three hours, when cortisone was acting maximally on sodium reabsorption. After oral cortisone (adjoining graph) the rise in GFR was delayed, and until this rise occurred sodium reabsorption remained almost complete.

Thus, cortisone had both vascular (GFR) and metabolic (tubular sodium reabsorption) effects on the kidney, which did not necessarily coincide in their points of maximal intensity. In acute

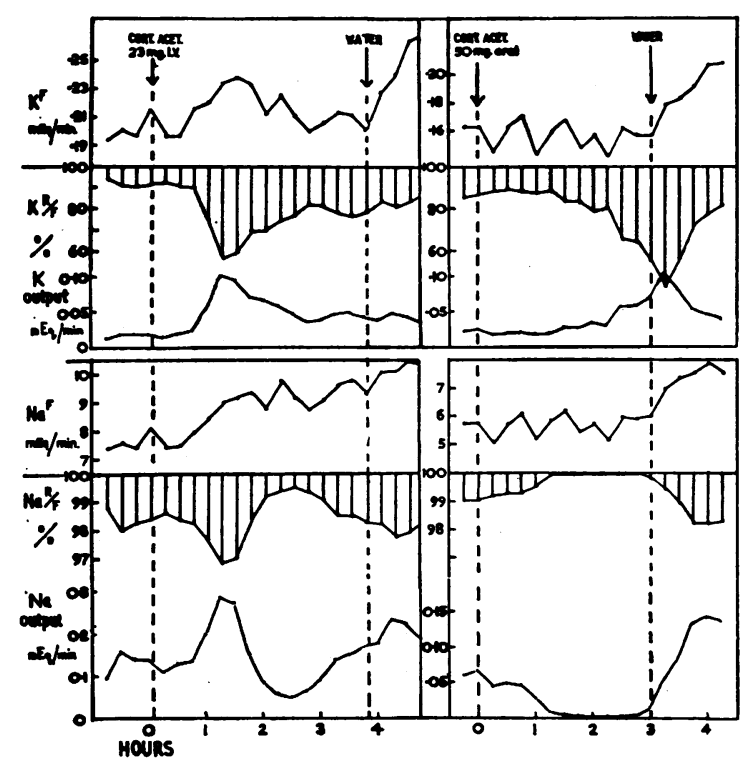

Fig. 7. The Efrect of Cortisone on Renal Sodium and Potassium Filtration and Reabsorption, in Adrenalectomized Dog A (Two Experiments)

The first experiment shows typical changes after intravenous cortisone. Independent of $\mathrm{Na}^{\mathrm{y}}$, tubular sodium reabsorption was greatest at about two and onehalf hours. In the second experiment, oral cortisone did not raise $\mathrm{Na}^{\mathrm{x}}$ acutely. Tubular sodium reabsorption was therefore complete until $\mathrm{Na}^{\mathrm{T}}$ rose after water ingestion. Changes in potassium excretion were largely independent of GFR. experiments the net result, which was increased sodium output, seemed to be due to preponderance of the filtration effect over the relatively weak tubular effect.

(d) In relation to intravenous $D C A$. Intravenous DCA, either alone or combined with cortisone, caused maximal tubular reabsorption of sodium within one and one-half hours, despite any rise in GFR due to the cortisone (Figures 4 and 6, Table II).

\section{Potassium excretion}

Both cortisone and DCA, given separately or together, caused an early rise in potassium excretion. This effect was largely independent of GFR and did not correlate closely with the changes in sodium excretion (Figures 4 and 7, Tables II and III).

\section{Anion excretion (Table II)}

During the first three hours after cortisone, the chloride excretion varied directly with the sum of the sodium and potassium excretion. During the next three hours this relationship ceased; chloride excretion then fell or remained steady, despite a further rise in cation excretion. Although the phosphate output always rose during the second three-hour period, by the fifth hour after cortisone the combined outputs of sodium and potassium exceeded those of chloride and phosphate by 60 to $100 \mu \mathrm{Eq}$. per minute. Because the urine was then of maximal alkalinity, ${ }^{12}$ most of this undetermined anion was probably bicarbonate. These changes did not occur after intravenous DCA.

\section{Diuresis after water ingestion ${ }^{18}$}

(a) Renal aspects of diuresis after adrenalectomy.

(i) The effects of chronic DCA therapy (Figure 8). Diuresis from water ingestion varied directly with the current level of DCA therapy.

12 The possibility that urinary infection might have contributed to the abnormally high urinary $\mathrm{pH}$ was not excluded.

18 Diuresis from the standard water dose was always greater when there was an accompanying infusion of creatinine and PAH. The two groups of experiments have therefore been shown separately in Figure 8. 
Compared with the pre-adrenalectomized state, ${ }^{14}$ during optimal DCA therapy both the onset and peak of diuresis were delayed, and the maximal rate of urinary flow and the percentage of the water dose excreted in three hours were both greatly diminished. During inadequate DCA therapy there were further delays in diuresis (Figure 2).

Excessive DCA therapy restored the pattern of diuresis almost to normal, as judged only by the urine volume. However, volume alone was not a true measure of water diuresis because of the

14 During the initial training period before adrenalectomy, at first diuresis was sometimes delayed and of poor volume. Because these failures seemed to be due to liberation of antidiuretic hormone, in response to catheterization, venepuncture, etc., data from these early experiments have not been included in this paper.

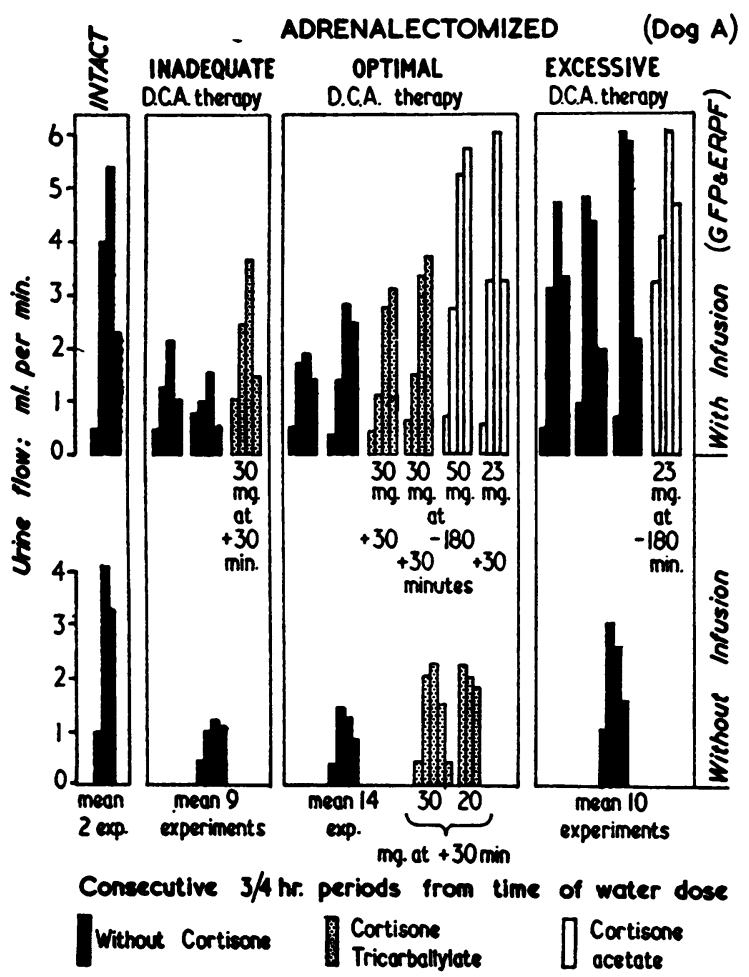

A high urinary sodium outputs (infra). In dog B, the delay in onset of diuresis was shortened by giving four times the optimal DCA therapy for three days, but the percentage of the water dose excreted in three hours was not increased (Figure 8). In this instance the higher DCA dosage was not continued for long enough to cause any gain in weight, hemodilution or elevation of GFR (Table I).

(ii) Acute effects of cortisone (Figure 8). Cortisone increased water diuresis above the control (adrenalectomized) volumes at each level of DCA therapy. After intravenous cortisone acetate this effect was seen within 60 to $90 \mathrm{~min}$ utes. Cortisone tricarballylate, somewhat slower in its action, augmented water diuresis before it raised GFR. In general, this effect of cortisone
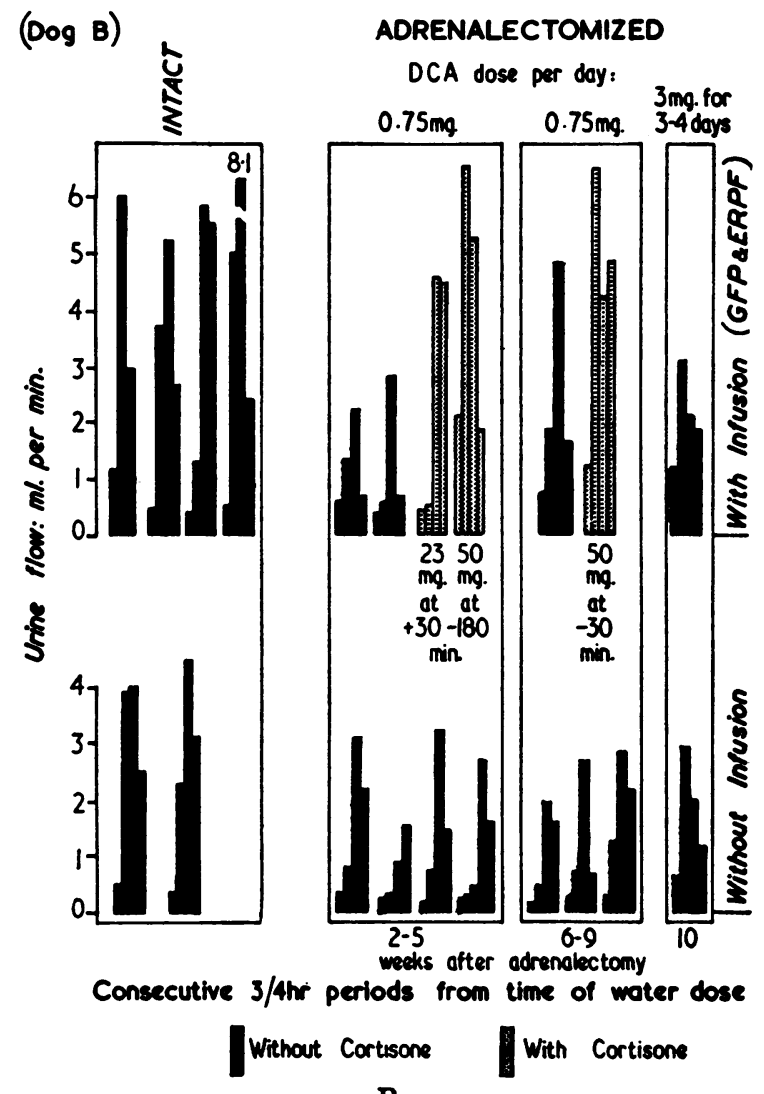

B

Fig. 8A and B. The Effects of Adrenalectomy, with and without Cortisone, on Acute Diuresis From INGESTED WATER

A standard water dose of $40 \mathrm{ml}$. per $\mathrm{Kgm}$. was given in all experiments. Because infusion of creatinine and PAH facilitated diuresis, the experiments in which GFR and ERPF were measured are shown separately. Figures below the data from cortisone experiments indicate the dose of cortisone, intravenous unless specified, and the time of its administration relative to the water dose. 

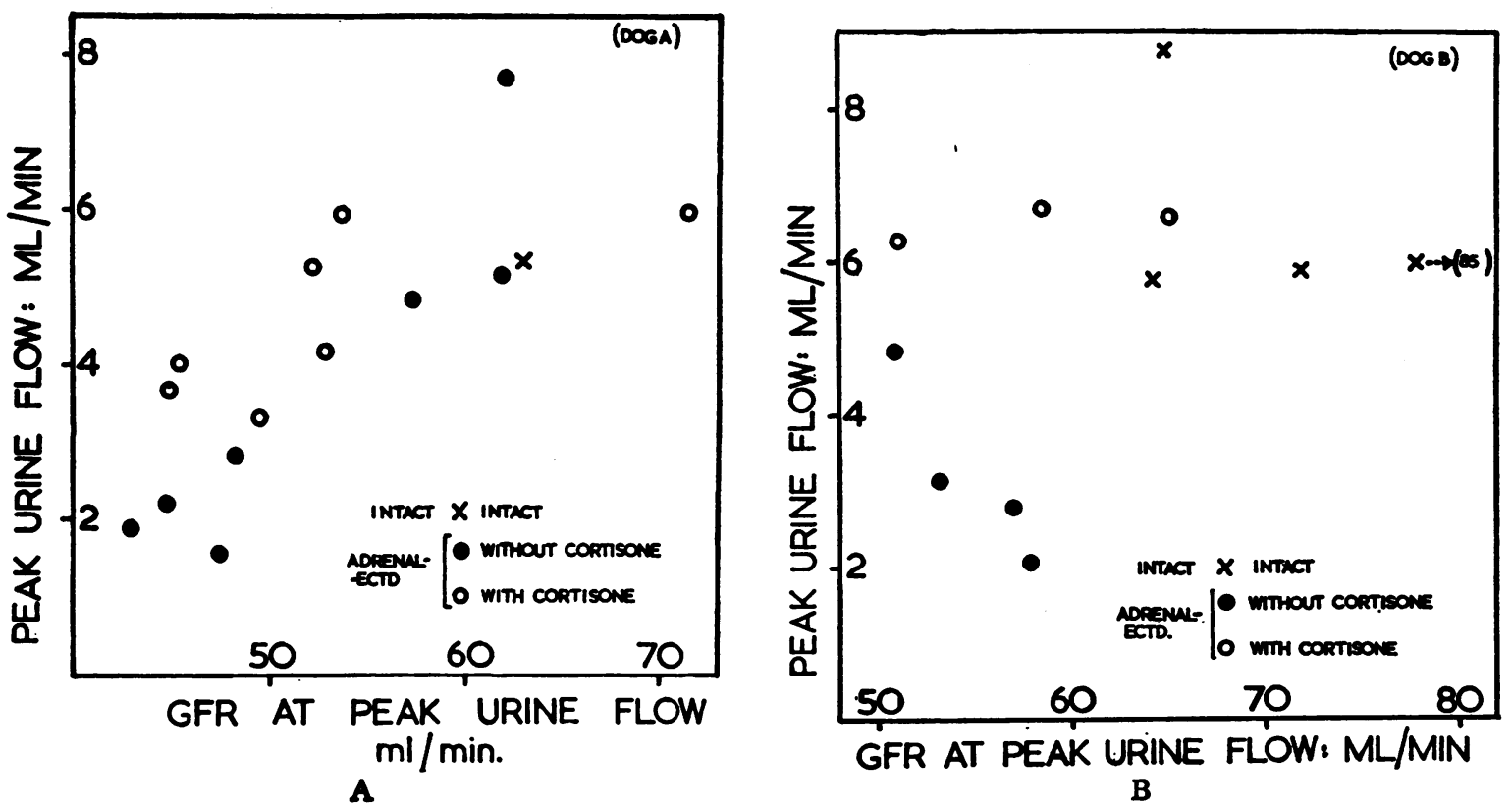

Fig. 9A and B. Maxtucal Urine Flow Relative to GFR during Diuresis in Two Adrenalectomizkd Dogs, WITH AND WITHOUT CORTISONE

All data plotted are the means of three consecutive 15-minute measurements, embracing the peak urine flow.

In $\operatorname{dog} B$ there was no relation between GFR and maximal urine flow. In both dogs cortisone increased maximal urine flow relative to GFR.

was largely independent of the level of GFR (Figure 9).

(iii) Acute effects of $D C A$ (Figure 4). Intravenous injection of $2.5 \mathrm{mg}$. of DCA did not increase water diuresis or augment the effect of cortisone on water diuresis.

(iv) Urine osmolarity and GFR. Urine osmolarity during the 45-minute peak of diuresis was calculated indirectly. ${ }^{15}$ No consistent relation was found between the level of GFR and the capacity to secrete a hypotonic urine. During diuresis after cortisone the urine osmolarity was much lower than in control experiments, irrespective of the level of GFR.

(b) Homeostatic aspects of water diuresis. The function of water diuresis is to correct acutely, by selective excretion of water, the dilution of body fluids which results from water ingestion. After adrenalectomy, though water ingestion caused normal hemodilution, ${ }^{16}$ the water loads

16 Calculated from the urinary concentrations of urea, creatinine, and (sodium and potassium $\times 2$ ).

16 The speed and magnitude of the fall in plasma specific gravity after water ingestion was the same after adrenalectomy as before. Water absorption from the gut was therefore presumed to be normal. were not excreted with normal rapidity, and the hemodilution persisted. These failures were acutely corrected by cortisone. The dilution of body fluids after water ingestion was measured by the falls in plasma specific gravity and sodium concentration. The return of these indices towards normal was then followed at intervals in relation to the total water excreted in excess of urinary isotonic sodium (Table V). In seven control experiments in the two adrenalectomized dogs, excluding the periods on excessive DCA therapy, at the end of three and three-fourths hours only 22 per cent of the water load had been excreted in this unobligated form and the plasma sodium concentration was still 5 per cent less than its initial value. In eight similar experiments with cortisone the findings, respectively, were 61 per cent excretion of water unobligated to sodium and 1.3 per cent reduction of the plasma sodium concentration. When the diuresis induced by cortisone after water ingestion was followed to its natural termination, the total urinary volume usually greatly exceeded the water load; yet, the total volume of urinary water unobligated to sodium, though sometimes equalling the water load, 
TABLE V

Plasma specific gravity and sodium concentration in relation to total water and sodium excretion, with and without cortisone (two adrenalectomised dogs) *

\begin{tabular}{|c|c|c|}
\hline $\begin{array}{l}\text { At three and three-fourths } \\
\text { hours after water }\end{array}$ & $\begin{array}{l}\text { Water without } \\
\text { cortisone } \\
\text { (7 expts.) }\end{array}$ & $\begin{array}{c}\text { Water } \\
\text { cortisone } \\
\text { (8 expts.) }\end{array}$ \\
\hline (40 ml./Kgm.) & Mean $\frac{\text { S.D. }}{\%}$ & Mean $\%$ S.D \\
\hline
\end{tabular}

Plasma Na conc.:

$\%$ change from initial level

$-5 \pm 1.1 \quad-1.3 \pm 2.1$

Plasma S.G.:

$\%$ change from initial level

Per cent of water dose excreted as total urinary water

Per cent of water dose excreted as water in excess of urinary isotonic sodium

$22.3 \pm 8.7$

$60.8 \pm 17.1$

* All experiments were accompanied by a standard infusion of creatinine and PAH the volume of which has been included in the total water dose. Experiments on $\operatorname{dog} A$ during excessive DCA therapy have been excluded. The differences after cortisone are significant $(p<.01)$.

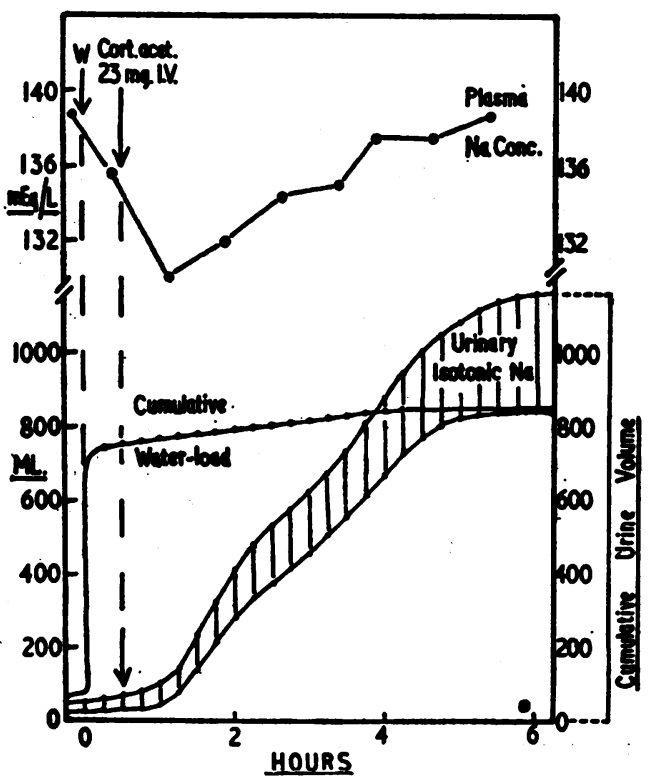

Fig. 10. The Effect of Cortisone on Sodium and Water Excretion during DTUResis, in Relation to Changes in Plasma Sodtum Concentration (AdRENALECTOMIZED Dog A)

The dog was on optimal DCA therapy. The volumes of the priming and sustaining infusions of creatinine and PAH in distilled water have been included in the water load. The end of water diuresis coincided with the return of the plasma sodium concentration to its initial level.

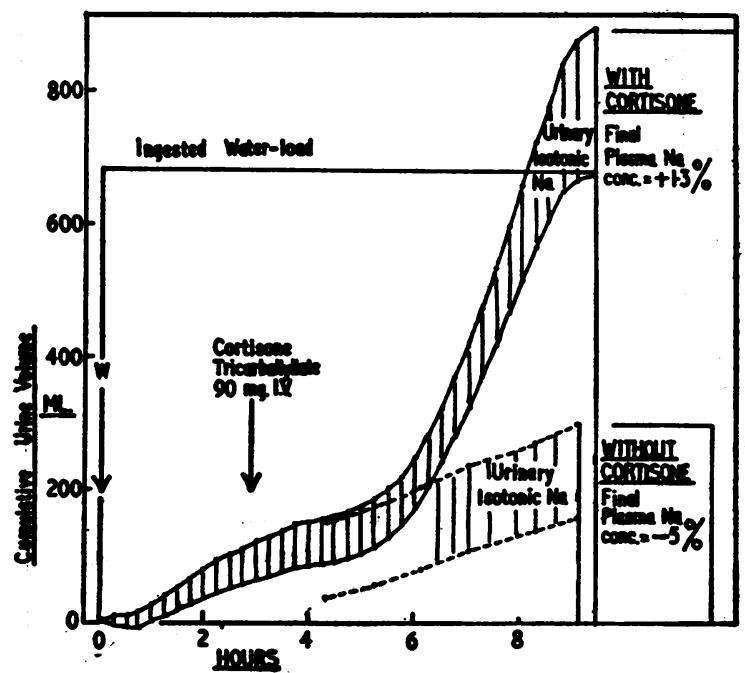

Fig. 11. Water Diuresis, with and without Cortisone, in Adrenalectomized Dog A

The two experiments were made without an infusion, when on optimal DCA therapy, with an interval of four days. At the end of diuresis after cortisone, the total water excreted in excess of total urinary isotonic sodium was equal to the water dose, and the plasma sodium concentration had returned to normal.

never exceeded it. By then the plasma sodium had returned to its initial concentration (Figures 10 and 11). The balance between the water load and the volume of unobligated water excreted was closest during cool weather, when insensible water loss was minimal. Thus, cortisone restored to normal the homeostatic function of water diuresis of correcting the plasma sodium hypotonicity, but did so at the expense of a negative balance of total body water.

\section{DISCUSSION}

Certain effects of adrenalectomy on the kidney are clearly secondary to loss of sodium. To measure other effects, which may not be dependent on sodium depletion, renal function must be studied under conditions of optimal bodily hydration, i.e., in a state of sodium and water balance comparable to that existing before adrenalectomy. Such conditions are probably best obtained by combining daily injections of DCA with a constant diet and a small addition of sodium chloride. The advantages of such a regimen over one of DCA implantation are that the dose can easily be adjusted to meet any departure from the optimal 
state, and that renal function can be assessed during its escape from DCA effect.

Using dogs of around $10 \mathrm{Kgm}$. weight, on an added salt intake of $2 \mathrm{gm}$. a day, other authors have shown that the minimal amounts of DCA needed for normal health and hydration are between 0.25 and $0.5 \mathrm{mg}$. a day $(10,11)$. With the same added salt, the dogs reported here needed 0.6 to $0.75 \mathrm{mg}$. a day which, allowing for their greater weight, is closely equivalent to the above amounts. Raising or lowering the dose of DCA by as little as $0.15 \mathrm{mg}$. was followed by consistent changes in body weight or in plasma specific gravity and electrolyte concentrations. Critical adjustment of the DCA therapy is thus essential for obtaining a steady optimal state, a precaution apparently overlooked in most previous studies.

After adrenalectomy the filtration rate seemed to vary with the state of bodily hydration, as was suggested by its inverse correlation with the plasma specific gravity, and by the over-retention of water which always accompanied the rise of filtration, whether chronic, as during excessive DCA therapy, or acute, from water ingestion or saline infusion. However, since filtration and renal blood flow remained subnormal even after optimal therapy had corrected any sodium depletion, at least a part of this failure could not be ascribed merely to reduction of the intravascular or extracellular fluid volumes. Some data on cardiac output are needed to throw further light on this problem.

The absence of any acute effect of DCA on filtration was in marked contrast with the rise in this function which occurred when excessive DCA therapy had caused over-retention of sodium and water. Though Davis and Howell found a subacute rise of filtration rate in the intact dog when DCA was given intramuscularly at more than twenty times the dosage used intravenously in the present experiments (32), this effect was considerably less than after cortisone or ACTH; and it is not clear from their data whether any sodium retention preceded the rise in filtration. It is possible, therefore, that DCA may have some primary action on the filtration rate when given in doses that are greatly excessive in terms of electrolyte effects.

The action of cortisone on the filtration rate and renal blood flow differs fundamentally from that of DCA in its rapidity of onset and its apparent independence of plasma volume or sodium balance. It would seem that cortisone has a "permissive" action of allowing a higher and more normal proportion to exist between the filtration rate and the level of bodily hydration. Whether this effect is confined to the kidneys or is part of a more widespread circulatory response cannot be decided from the present data.

The normal dog excretes a sodium load more rapidly than does man, and puts out only negligible amounts of sodium after 18 hours of fasting. The sodium output falls further during sustained maximal water diuresis ( 31$)$, and, as has been shown in the present studies, either falls or increases only slightly when the filtration rate rises during acute water diuresis. After adrenalectomy, however, there is a partial loss of tubular ability to conserve sodium, and the filtration rate becomes the main regulator of sodium output. The adrenalectomized dog comes to resemble the saltloaded normal dog in that both show a direct relation between sodium filtration and sodium output (33). This could be explained by assuming that salt-loading of the intact animal may suppress the secretion of a powerful sodium-retaining steroid, whereas in the normal fasting state this steroid ${ }^{17}$ may already be present in amounts large enough to prevent any increase in sodium output when filtration rises after water ingestion.

Although its sodium-retaining action is well recognized (4), cortisone often increases sodium excretion $(15,18,19,36,37)$. To explain this paradox, it has been suggested that under certain conditions, notably in the presence of DCA, cortisone may inhibit tubular reabsorption of sodium (15); and a concept has arisen of intratubular competition between cortisone and a steroid with more potent sodium-retaining effects, which cortisone is supposed to displace (17). This hypothesis ignores the important role of filtration rate in regulating sodium output. In the present studies it has been shown that after cortisone there is still a clear correlation between filtration rate and sodium output, though the latter is slightly less, and the fraction of filtered sodium reabsorbed slightly higher, than at parallel levels of filtration without cortisone. Thus, though cortisone in-

17 Probably aldosterone $(34,35)$. 
creases sodium reabsorption, this effect is not enough to prevent a net increase in sodium output in the presence of increased filtration of this ion. Similarly, Davis and Howell found in the intact dog that a great natriuresis accompanied the rise in filtration induced by cortisone or ACTH (32); and, though Roberts and Pitts did not find this effect in the adrenalectomized dog, it should be noted that there were no changes in filtration rate during the short periods of their experiments (14).

When DCA and cortisone were given together, reabsorption of sodium became almost complete, despite increased filtration. Similarly, Roberts and Pitts have shown that these two steroids have a summative effect on sodium reabsorption (14). Since the natriuretic effects of cortisone can now be adequately explained by increased filtration, there is no further need to invoke the hypothesis of competition between these steroids at the renal tubular level.

It is still a matter of dispute why adrenal failure should inhibit the capacity for water diuresis. The main issue concerns the cause of the renal failure to excrete a more hypotonic urine after water ingestion, despite adequate hemodilution (8, 13). Theoretically, this failure could be due either to extrarenal factors, such as continued secretion of antidiuretic hormone (ADH), or to intrinsic renal disturbances, conditioned by lack of adrenal hormones, and independent of the presence or absence of $\mathrm{ADH}$. To consider first the present data on renal factors: when a normal filtration rate was restored by forced water ingestion during excessive DCA therapy, the ability to excrete a hypotonic urine, though still diminished, was greatly improved. Because the possibility of there having been any direct effect of DCA during these experiments seems to have been excluded by the high sodium outputs, and because DCA did not acutely correct filtration rate or water diuresis, it could be argued that the improved diuresis was somehow related to increased filtration. On the other hand, when cortisone restored the capacity for a normal water diuresis, the increased output of a more hypotonic urine sometimes occurred before filtration had risen. It is thus probable that an abnormality of tubular function, whether primary or secondary to $\mathrm{ADH}$, is the essential factor in causing inhibition of water diuresis, though lowered filtration rate probably plays an additional role.

To consider next the evidence concerning extrarenal factors: it has been suggested that the action of $\mathrm{ADH}$ may be prolonged unduly in adrenal failure because of delayed inactivation of this hormone by the liver (38). However, this does not explain why water diuresis should end prematurely, after only a small fraction of the water load has been excreted, instead of continuing to increase slowly as the inactivation of $\mathrm{ADH}$ proceeds. If $\mathrm{ADH}$ be the paramount factor, it must therefore be postulated that this hormone is being continuously secreted during the long period of delayed diuresis. The secretion of $\mathrm{ADH}$ might so persist either because the osmoreceptors cannot function at their normal threshold when deprived of adrenal hormones, or because there is a further unidentified stimulus to $\mathrm{ADH}$ secretion, possibly humoral or arising from volume receptors.

\section{SUMMARY}

Changes in GFR, ERPF, electrolyte excretion, and water diuresis were studied in two adrenalectomized dogs in relation to bodily hydration and to acute administration of cortisone and DCA.

The dogs received daily DCA therapy which was assessed by its effects on bodily hydration as inadequate, optimal or excessive. Renal function was measured during the daily escape from DCA effect.

After adrenalectomy GFR and ERPF were subnormal on optimal DCA therapy, but rose after water-loading or saline infusion. DCA had no acute effect on GFR and raised it only when causing excessive retention of sodium and water. Cortisone raised GFR acutely, without change in plasma volume and despite a negative sodium balance.

After adrenalectomy, during escape from DCA effect, the sodium output varied directly with GFR. DCA caused acute maximal sodium retention. Cortisone usually increased the sodium output by raising GFR, thereby obscuring its other effect of slightly increasing tubular sodium reabsorption at any given level of filtration.

After adrenalectomy, water diuresis was greatly diminished, and was acutely restored by cortisone, 
but not by DCA. This effect of cortisone was largely independent of GFR and electrolyte outputs.

After adrenalectomy, water ingestion caused prolonged hyponatremia which cortisone corrected by allowing excretion of the water load plus a volume of water isotonically equivalent to the urinary sodium. The plasma sodium concentration was thereby restored at the expense of total body water.

These results suggest that in the adrenalectomized dog: 1) There is a direct relationship between extracellular hydration and GFR, and between GFR and sodium output; and 2) that two adrenal steroids are needed to maintain normal renal function: (a) cortisone or hydrocortisone, to maintain normal GFR and water diuresis, and (b) a DCA-like steroid, to prevent excessive sodium excretion at normal or high levels of GFR.

\section{Addendum}

Since this paper was submitted for publication, acute effects of cortisone and DCA on GFR and sodium excretion in the adrenalectomized dog, which are similar to those reported here, have been described by Liddle, Pechet, and Bartter (39).

\section{ACKNOWLEDGMENTS}

The authors wish to express their gratitude to Dr. R. F. Loeb for encouragement and advice and for providing the facilities for this study; to Dr. Alfred Gilman for advice; to Dr. David Habif for undertaking the adrenalectomies; to Dr. T. Allen for assistance in measuring plasma volumes; and to Dr. Russell T. Fraser for criticism of the manuscript.

They also wish to thank Merck and Co. of New Jersey for providing the cortisone tricarballylate, and Chemical Specialities, Inc., of New York, for providing the microcrystalline suspensions of cortisone acetate and DCA.

\section{REFERENCES}

1. Loeb, R. F., Atchley, D. W., Benedict, E. M., and Leland, J. L., Electrolyte balance studies in adrenalectomised dogs with particular reference to the excretion of sodium. J. Exper. Med., 1933, 57, 775.

2. Harrop, G. A., Jr., Soffer, L. J., Ellsworth, R., and Trescher, J. H., Studies on the suprarenal cortex; III. Plasma electrolytes and electrolyte excretion during suprarenal insufficiency in dog. J. Exper. Med., 1933, 58, 17.

3. Harrison, H. E., and Darrow, D. C., Renal function in experimental adrenal insufficiency. Am. J. Physiol., 1939, 125, 631.
4. Gaudino, M., and Levitt, M. F., Influence of the adrenal cortex on body water distribution and renal function. J. Clin. Invest., 1949, 28, 1487.

5. Talbott, J. H., Pecora, L. J., Melville, R. S., and Consolazio, W. V., Renal function in patients with Addison's disease and in patients with adrenal insufficiency secondary to pituitary pan-hypofunction. J. Clin. Invest., 1942, 21, 107.

6. Waterhouse, C., and Keutmann, E. H., Kidney function in adrenal insufficiency. J. Clin. Invest., 1948, 27, 372.

7. Kottke, F. J., Code, C. F., and Wood, E. H., Urine dilution and concentration tests in adrenalectomised dogs. Am. J. Physiol., 1942, 136, 229.

8. Roemmelt, J. C., Sartorius, O. W., and Pitts, R. F., Excretion and reabsorption of sodium and water in the adrenalectomised dog. Am. J. Physiol., 1949, 159, 124.

9. White, H. L., Heinbecker, P., and Rolf, D., Further observations on the depression of renal function following hypophysectomy. Am. J. Physiol., 1949, $156,67$.

10. Remington, J. W., Parkins, W. M., Swingle, W. W., and Drill, V. A., Efficacy of desoxycorticosterone acetate as replacement therapy in adrenalectomized dogs. Endocrinology, 1941, 29, 740.

11. Cleghorn, R. A., Fowler, J. L. A., Wenzel, J. S., and Clarke, A. P. W., The desoxycorticosterone acetate requirement of the adrenalectomised dog. Endocrinology, 1941, 29, 535.

12. Burnett, C. H., The actions of ACTH and cortisone on renal function in man in Renal Function, Transactions of the Second Conference, Oct. 1950, S. E. Bradley, ed., New York, Josiah Macy, Jr. Foundation, 1951, p. 106.

13. Burston, R. A., and Garrod, O., The variability of the lowered glomerular filtration rate in Addison's disease and panhypopituitarism and the effect of cortisone thereon. Clin. Sc., 1952, 11, 129.

14. Roberts, K. E., and Pitts, R. F., The influence of cortisone on renal function and electrolyte excretion in the adrenalectomized dog. Endocrinology, 1952, 50, 51.

15. Thorn, G. W., Forsham, P. H., Bennett, L. L., Roche, M., Reiss, R. S., Slessor, A., Flink, E. B., and Somerville, W., Clinical and metabolic changes in Addison's disease following the administration of compound E acetate. Tr. A. Am. Physicians, 1949, 62, 233.

16. Garrod, O., and Burston, R. A., The diuretic response to ingested water in Addison's disease and panhypopituitarism and the effect of cortisone thereon. Clin. Sc., 1952, 11, 113.

17. Adrenal Cortex: Transactions of the Third Conference, Nov. 1951, E. P. Ralli, ed., New York, Josiah Macy, Jr. Foundation, 1952.

18. Thorn, G. W., Engel, L. L., and Lewis, R. A., The effect of 17-hydroxycorticosterone and related adrenal cortical steroids on sodium and chloride excretion. Science, 1941, 94, 348. 
19. Davis, A. K., Bass, A. C., and Overman, R. R., Comparative effects of cortisone and DCA on ionic balance and fluid volume of normal and adrenalectomised dogs. Am. J. Physiol., 1951, 166, 493.

20. Swingle, W. W., Collins, E., Barlow, G., and Fedor, E. J., Bioassay and physiological effects of cortisone on adrenalectomized dogs. Am. J. Physiol., 1952, 169, 270.

21. Gregersen, M. I., and Stewart, J. D., Simultaneous determination of the plasma volume with $T-1824$, and the "available fluid" volume with thiocyanate. Am. J. Physiol., 1939, 125, 142.

22. Berry, J. W., Chappel, D. G., and Barnes, R. B., An improved method of flame photometry. Indust. \& Engin. Chem. (Anal. Ed.), 1946, 18, 19.

23. Van Slyke, D. D., The determination of chlorides in blood and tissues. J. Biol. Chem., 1923, 58, 523.

24. Folin, O., and $W u, H ., A$ system of blood analysis. J. Biol. Chem., 1919, 38, 81.

25. Smith, H. W., Finkelstein, N., Aliminosa, L., Crawford, B., and Graber, M., The renal clearances of substituted hippuric acid derivatives and other aromatic acids in dog and man. J. Clin. Invest., 1945, 24, 388.

26. Fiske, C. H., and Subbarow, Y., The colorimetric determination of phosphorus. J. Biol. Chem., 1925, 66, 375.

27. Gentskow, C. J., An accurate method for the determination of blood urea nitrogen by direct nesslerization. J. Biol. Chem., 1942, 143, 531.

28. Phillips, R. A., Van Slyke, D. D., Dole, V. P., Emerson, K., Jr., Hamilton, P. B., and Archibald, R. M., Copper Sulphate Method for Measuring Specific Gravities of Whole Blood and Plasma. Glendale, Calif., Dan. Baxter, Inc., 1945.
29. Lowry, O. H., and Hunter, T. H., The determination of serum protein concentration with a gradient tube. J. Biol. Chem., 1945, 159, 465.

30. Courtice, F. C., The blood volume of normal animals. J. Physiol., 1943, 102, 290.

31. Gilman, A., Personal Communications.

32. Davis, J. O., and Howell, D. S., Comparative effect of ACTH, cortisone and DCA on renal function, electrolyte excretion and water exchange in normal dogs. Endocrinology, 1953, 52, 245.

33. Thompson, D. D., and Pitts, R. F., Effects of alterations of renal arterial pressure on sodium and water excretion. Am. J. Physiol., 1952, 168, 490.

34. Simpson, S. A., Tait, J. F., and Bush, I. E., Secretion of a salt-retaining hormone by the mammalian adrenal cortex. Lancet, 1952, 2, 226.

35. Mach, R. S., Fabre, J., Duckert, A., Borth, R., and Ducommun, P., Action clinique et metabolique de l'Aldosterone (electrocortine). Schweiz. med. Wchnschr., 1954, 84, 407.

36. Marcus, F., Romanoff, L. P., and Pincus, G., The electrolyte-excreting activity of adrenocortical substances. Endocrinology, 1952, 50, 286.

37. Perera, G. A., Pines, K. L., Hamilton, H. B., and Vislocky, K., Clinical and metabolic study 11dehydro-17-corticosterone acetate (Kendall compound $\mathrm{E}$ ) in hypertension, Addison's disease and diabetes mellitus. Am. J. Med., 1949, 7, 56.

38. Birnie, J. H., The inactivation of posterior pituitary antidiuretic hormone by liver extracts. Endocrinology, 1953, 52, 33.

39. Liddle, G. W., Pechet, M. M., and Bartter, F. C., Enhancement of biological activities of corticosteroids by substitution of halogen atoms in $9 \alpha$ position. Science, 1954, 120, 496.

\section{SPECIAL NOTICE TO SUBSCRIBERS}

Post Offices will no longer forward the Journal when you move.

Please notify The Journal of Clinical Investigation, Business Office, 622 West 168th Street, New York 32, N. Y. at once when you have a change of address, and do not omit the zone number if there is one. 